\title{
Biphasic Changes in Locomotor Behavior and in Expression of mRNA for NGFI-A and NGFI-B in Rat Striatum Following Acute Caffeine Administration
}

\author{
Per Svenningsson, George G. Nomikos, and Bertil B. Fredholm \\ Department of Physiology and Pharmacology, Center for Pharmacology, Karolinska Institutet, S-171 77 Stockholm, \\ Sweden
}

\begin{abstract}
The time course of expression of mRNA for NGFI-A and NGFI-B after a single intraperitoneal injection of saline or caffeine was examined using in situ hybridization. Administration of a high dose of caffeine $(100 \mathrm{mg} / \mathrm{kg})$ decreased locomotor behavior and increased NGFI-A and NGFI-B mRNA in the entire striatum. A lower dose of caffeine (50 $\mathrm{mg} / \mathrm{kg}$ ) caused a weak enhancement of both messages, which was confined to the lateral part of caudate-putamen. This dose increased horizontal, but not vertical, movement. In rats treated with the lowest dose of caffeine $(25 \mathrm{mg} / \mathrm{kg})$, the expression of both investigated genes tended to be lower than for saline-treated rats and both horizontal and vertical locomotor activity increased markedly. The reduction in the number of labeled neurons seemed to occur predominantly in enkephalin-containing neurons, which coexpress adenosine $A_{2 A}$ receptors and dopamine $D_{2}$ receptors. The decrease of mRNA for NGFI-A, NGFI-B, and jun B caused by caffeine $(25 \mathrm{mg} / \mathrm{kg})$ could be mimicked by the $D_{2}$ agonist quinpirole (1 and $3 \mathrm{mg} / \mathrm{kg}$ ). Moreover, caffeine could significantly decrease the expression seen following treatment with the $D_{2}$ antagonist raclopride $(2 \mathrm{mg} / \mathrm{kg})$. In addition, in the parietal cortex, $25 \mathrm{mg} / \mathrm{kg}$ of caffeine caused a significant elevation of both examined immediate early genes.
\end{abstract}

Thus, biphasic changes in locomotion induced by caffeine are paralleled by biphasic changes in mRNA for NGFIA, NGFI-B, and jun B. The results also provide additional support for a functionally important interaction between adenosine and dopamine $D_{2}$ receptors.

[Key words: caffeine, adenosine $A_{2 A}$ receptors, immediate early genes, striatum, in situ hybridization, behavior]

Caffeine is the most widely consumed of all psychoactive drugs. Its actions seem to be primarily due to antagonism at adenosine receptors (for reviews, see Fredholm, 1980; Nehlig et al., 1992; Daly, 1993; Fredholm, 1995). Four different adenosine receptors have been cloned and pharmacologically identified: $A_{1}, A_{2 A}, A_{2 B}$, and $\mathrm{A}_{3}$ (Fredholm et al., 1994). The first two are likely to be

\footnotetext{
Received Mar. 30, 1995; revised June 9, 1995; accepted July 21, 1995.

We thank Janet Holmén for help in the preparation of this manuscript. These studies were supported by grants from the Swedish Medical Research Council (Project 02553), the Institule for Scientific Infurnation on Coffee, and Karolinska Institutet. G.G.N. is the recipient of a fellowship from the Swedish Medical Research Council.

Correspondence should be addressed to Per Svenningsson at the above ad dress.

Copyright (C) 1995 Society for Neuroscience $0270-6474 / 95 / 157612-13 \$ 05.00 / 0$
}

the primary targets of caffeine action because they are stimulated by adenosine in physiological concentrations and blocked by relevant caffeine concentrations (Fredholm, 1995). Adenosine $A_{1}$ receptors are predominantly expressed in cerebral cortex, hippocampus, some thalamic nuclei and cerebellar cortex, but are also located in striatum (Fastbom et al., 1987). The IIIRNA for adenosine $A_{1}$ receptors is, however, only weakly expressed in the striatum (Johansson et al., 1993a), suggesting that the striatal $A_{1}$ receptors may be localized to terminals of neurons whose cell bodies are elsewhere. Adenosine $A_{2 \mathrm{~A}}$ receptors are enriched in the striatum (Parkinson and Fredholm, 1990), and so is the corresponding mRNA (Johansson et al., 1993a), indicating a localization to intrinsic neurons. Indeed the adenosine $A_{2 A}$ receptors may be confined to pallidal-projecting GABAergic enkephalin-containing neurons, which also express dopamine $D_{2}$ receptors (Fink et al., 1992; Schiffmann et al., 1991). This is important hecause an interaction between $A_{2 A}$ and $D_{2}$ receptors may play a critically important role for the psychostimulatory effects of caffeine (Ferre et al., 1991). Activation of $A_{2 A}$ receptors increases intracellular levels of cAMP (Fredholm et al., 1994), whereas $D_{2}$ receptors mediate the opposite effect on intracellular cAMP levels (Senogles, 1994). In striatal membranes $A_{2 A}$ agonists can decrease the binding of $D_{2}$ agonists to the dopamine $D_{2}$ receptors and also decrease the dopamine induced inhibition of a $\mathrm{D}_{2}$ antagonist's binding (Ferre et al., 1991). Both these effects were inhibited by $\mathrm{A}_{2 \Lambda}$ antagonists. Moreover, it has long been recognized that methylxanthines, like caffeine, potentiate dopamine-induced hyperactivity (Fredholm et al., 1976; Ferré et al., 1992) and that dopamine receptor antagonists can inhibit the stimulatory effects of caffeine (Josselyn and Beninger, 1991; Garrett and Holtzman, 1994b). In addition, long-term treatment of rats with caffeine reduces the effects of both caffeine and dopamine receptor agonists (Garrett and Holtzman, 1994a).

We and others have previously reported that caffeine, at doses above $50 \mathrm{mg} / \mathrm{kg}$, can induce c-fos, jun $\mathrm{B}$ and c-jun in rat striatum (Johansson et al., 1994; Nakajima et al., 1989; Svenningsson et al., 1995), whereas no significant effects are seen following administration of lower-and pharmacologically more relevantdoses of caffeine. Furthermore the stimulant effects of high doses of caffeine on immediate early gene expression are observed not only in striatopallidal neurons expressing high levels of the $A_{2 \mathrm{~A}}$ receptors, but also in the striatonigral GABAergic neurons where such receptors cannot be found (Johansson et al., 1994; Svenningsson et al., 1995). Since these high doses of caffeine lead to a behavioral depression in experimental animals (see 
Daly, 1993) the induction of immediate early gene expression might reflect behavioral depression rather than the behavioral stimulation that is the basis for the widespread human use of caffeine. In order to try to find an effect of lower doses of caffeine we studied the regulatory role of caffeine also on the expression of NGFI-A mRNA and NGFI-B mRNA ${ }^{1}$. It is known that the basal expression of mRNA for NGFI-A (Milbrandt, 1987) and NGFI-B (Milbrandt, 1988) is relatively high in striatum (Schlingensiepen et al., 1991; Watson and Milbrandt, 1990; Worley et al., 1991; Bhat et al., 1992). Several studies have shown that the striatal levels of NGFI-A mRNA can be regulated via dopaminergic transmission and an increase in the expression of the gene is seen following treatment with $D_{1}$ agonists, $D_{2}$ antagonists and indirect dopamine agonists like cocaine and amphetamine (Cole et al., 1992; Moratalla et al., 1992; Nguyen et al., 1992). Additionally, and more pertinent to our study, it has been reported that a significant reduction of NGFI-A mRNA occurs following chronic treatment with cocaine (Bhat et al., 1992).

Here we report that a single injection of caffeine in a dose that increased motor activity also caused a persistent and significant decrease in the expression of mRNA for NGFI-A, NGFI-B, and jun B throughout striatum, especially in striatopallidal neurons. Conversely a behaviorally depressant dose caused a marked induction of these genes, followed after several hours by a significantly reduced expression. The caffeine-induced decrease of NGFI-A mRNA and NGFI-B mRNA was mimicked by a $\mathrm{D}_{2}$ agonist. These results provide evidence for the notion that caffeine-induced locomotor stimulation is related to increased dopaminergic input to striatopallidal neurons.

\section{Materials and Methods}

Measurement of locomotion following treatment with caffeine. Malc Sprague-Dawley rats weighing 210-270 gm (ALAB, Stockholm, Sweden) were accustomed to the experimenter by being handled on 2 consecutive days before the experiment. On the experimental day, they were randomly assigned to various groups and injected intraperitoneally with a single dose of saline or caffeine (Sigma, Labkemi, Stockholm, Sweden) 25,50 , and $100 \mathrm{mg} / \mathrm{kg}$. Immediately thereafter locomotion was measured for $8 \mathrm{hr}$ in a large square arena $(68 \times 68 \times 45 \mathrm{~cm})$ equipped with photocells at two levels for recording of horizontal (locomotion) and vertical (rearing) activity (Ericson et al., 1991). The rats were only used in one experimental session.

Tissue preparation for in situ hybridization. Male Sprague-Dawley rats weighing $200-230 \mathrm{gm}$ (ALAB, Stockholm, Sweden) were used. In a first experiment, rats were injected intraperitoneally with a single dose of saline or caffeine 25,50 , or $100 \mathrm{mg} / \mathrm{kg}$. Thirty minutes, $1 \mathrm{hr}, 2 \mathrm{hr}$, $4 \mathrm{hr}$, or $8 \mathrm{hr}$ after injection rats were briefly anesthetized with $\mathrm{CO}_{2}$ and killed immediately by decapitation. The brains were dissected out and frozen on dry ice. In a second experiment, rats were injected with saline or caffeine $25 \mathrm{mg} / \mathrm{kg}$ and in addition, the dopamine $\mathrm{D}_{2}$ receptor agonist quinpirole (Research Biochemicals International, Natick, MA, USA; 1

NGFI-A, NGF-induced clone A, is also termed zif/268 (Christy et al., 1988), Krox-24 (Lemaire et al., 1988), and EGK-I (Sukhatme et al., 198/). NGHI-B, NGF-induced clone B, is also termed nur/77 (Hazel et al., 1988). or $3 \mathrm{mg} / \mathrm{kg}$ ) or the dopamine $\mathrm{D}_{2}$ receptor antagonist raclopride ( $\Lambda$ stra, Södertälje, Sweden; $2 \mathrm{mg} / \mathrm{kg}$ ) were administered alone or in combination with caffeine $(25 \mathrm{mg} / \mathrm{kg})$. Four hours after treatment, rats were killed and the brains dissected out as in the first experiment. Consecutive coronal sections ( 5 and $14 \mu \mathrm{m}$ ) were made through the rostral part of striatum (with $+1.5 \mathrm{~mm}$ from bregma as a landmark) and thawmounted on poly-L-lysine $(50 \mu \mathrm{g} / \mathrm{ml})$ coated slides.

In situ hybridization. The following oligodeoxynucleotide probes were used: NGFI-A mRNA, 45 bases long, complementary to mRNA encoding amino acids $2-16$ of the rat NGFI-A protein (Milbrandt, 1987) NGFI-B mRNA, 45 bases long, complementary to mRNA encoding amino acids $1-15$ of the rat NGFI-B protein (Milbrandt, 1988); jun B, 48 bases long, complementary to mRNA encoding amino acids 195 210 of the mouse Jun B protein (Ryder et al., 1988); enkephalin mRNA, 48 bases long, complementary to nucleotides $388-435$ of the rat preproenkephalin gene (Yoshikawa et al., 1984); substance P mRNA, 48 bases long, complementary to nucleotides 124-171 of the rat preprotachykinin A gene (Krause et al,, 1987). All probes were synthesized by Scandinavian Gene Synthesis AB, Köping, Sweden, and have been tested for specificity (Wisden et al., 1990; Moratalla et al., 1993; Johansson et al., 1994). Oligodeoxynucleotide probes were radiolabeled using terminal deoxynucleotidyl transferase (Pharmacia LKB, Uppsala, Sweden) and $\alpha^{-35}$ S-dATP (Du Pont, New England Nuclear, Stockholm, Sweden) to a spccific activity of about $10^{\circ} \mathrm{cpm} / \mu \mathrm{g}$. Sections were hybridized in a cocktail containing 50\% deionized formamide (Fluka, Buchs, Switzerland), $4 \times$ SSC, $1 \times$ Denhardt's solution, $1 \%$ sarcosyl, $0.02 \mathrm{M} \mathrm{NaPO}_{4}(\mathrm{pH} 7.0$ ), $10 \%$ dextran sulfate, 0.5 mg/ml yeast IRNA (Sigma, Labkemi, Stockholm, Sweden), $0.06 \mathrm{M}$ dithiothreitol, $0.1 \mathrm{mg} /$ $\mathrm{ml}$ sheared salmon sperm DNA, and $10^{7} \mathrm{CPM} / \mathrm{ml}$ of probe. After hybridization for $15 \mathrm{hr}$ at $42^{\circ} \mathrm{C}$, the sections were washed four times, for 15 min each, in $1 \times \mathrm{SSC}$ at $55^{\circ} \mathrm{C}$, dipped briefly in water, $70 \%, 95 \%$, and $99.5 \%$ ethanol and air-dried. The sections were apposed to Hyperfilm- $\beta_{\max }$ film (Amersham, Solna, Sweden) for $3-5$ weeks or dipped in NTB-3 emulsion (Kodak, Järfälla, Sweden) and exposed for 6 weeks. After the emulsion had been developed, sections were lightly counterstained in $0.5 \%$ cresyl violet.

Films were analyzed with a Microcomputer Imaging Device (Imaging Research, St. Catharines, Canada). Before measurements, the computer was calibrated with a Kodak density wedge. Results are presented as optical density units and film background was subtracted from all measured values. Emulsion autoradiograms were evaluated by inspection in light microscope. Cells with the appearance of medium-sized spiny neurons (11-13 $\mu \mathrm{m}$ in diameter) that showed a grain density at least four times the background were considered to be labeled, the remaining cells unlabeled. In order to study colocalization of signals, $5 \mu \mathrm{m}$ thin paired consecutive sections were used. Under low power magnification, landmark structures (vessels) were identificd in the consccutive scctions. Under higher power, groups of cells that could be identified in both sections were noted, and finally, under highest magnification, grains were identified and counted.

Statistics. For data obtained by in situ hybridization, differences between means \pm SEM were analyzed by single-factor analysis of variance (ANOVA) (GRAPHPAD INSTAT; ISI Software) followed by pairwise group comparisons by the Tukey-Kramer method (Systat), and for analyzing the results of colocalization studies, $\chi^{2}$ test (GRAPHPAD, INSTAT) was used.

Results from the behavioral experiment were normalized by a square root transformation and analyzed by two-way (treatment $\times$ time) ANOVA followed by Newman-Keuls test for pairwise comparisons (CSS: STATISTICA software).

\section{Results}

In situ hybridization studies

Effect of a single injection of caffeine on the expression of NGFI-A MRNA in striatum. In agreement with previous reports

\footnotetext{
Figure 1. In situ hybridization autoradiograms showing the distribution of NGFI-A mRNA expression in coronal sections of brain (a) of rats treated with saline or caffeine $(25 \mathrm{mg} / \mathrm{kg}, 50 \mathrm{mg} / \mathrm{kg}$, or $100 \mathrm{mg} / \mathrm{kg})$ and sacrificed after $30 \mathrm{~min}, 1 \mathrm{hr}, 2 \mathrm{hr}, 4 \mathrm{hr}$, or $8 \mathrm{hr}$. At the cellular level $(b)$ NGFI-A mRNA induction was clearly stronger after caffeine $(100 \mathrm{mg} / \mathrm{kg}$, top) than after saline (bottom). Both rats were sacrificed 1 hr after injection.

Figure 2. In situ hybridization autoradiograms showing the distribution of NGFI-B mRNA expression in coronal sections of brain of rats treated with saline or caffeine $(25 \mathrm{mg} / \mathrm{kg}, 50 \mathrm{mg} / \mathrm{kg}$, or $100 \mathrm{mg} / \mathrm{kg})$ and sacrificed after $30 \mathrm{~min}, 1 \mathrm{hr}, 2 \mathrm{hr}, 4 \mathrm{hr}$, or $8 \mathrm{hr}$. Some of slides were thereafter dipped in emulsion. $b$ shows neuron-like cells expressing NGFI-B mRNA in rats treated with saline (bottom) or caffeine $100 \mathrm{mg} / \mathrm{kg}$ (top) and sacrificed $1 \mathrm{hr}$ after injection.
} 
A

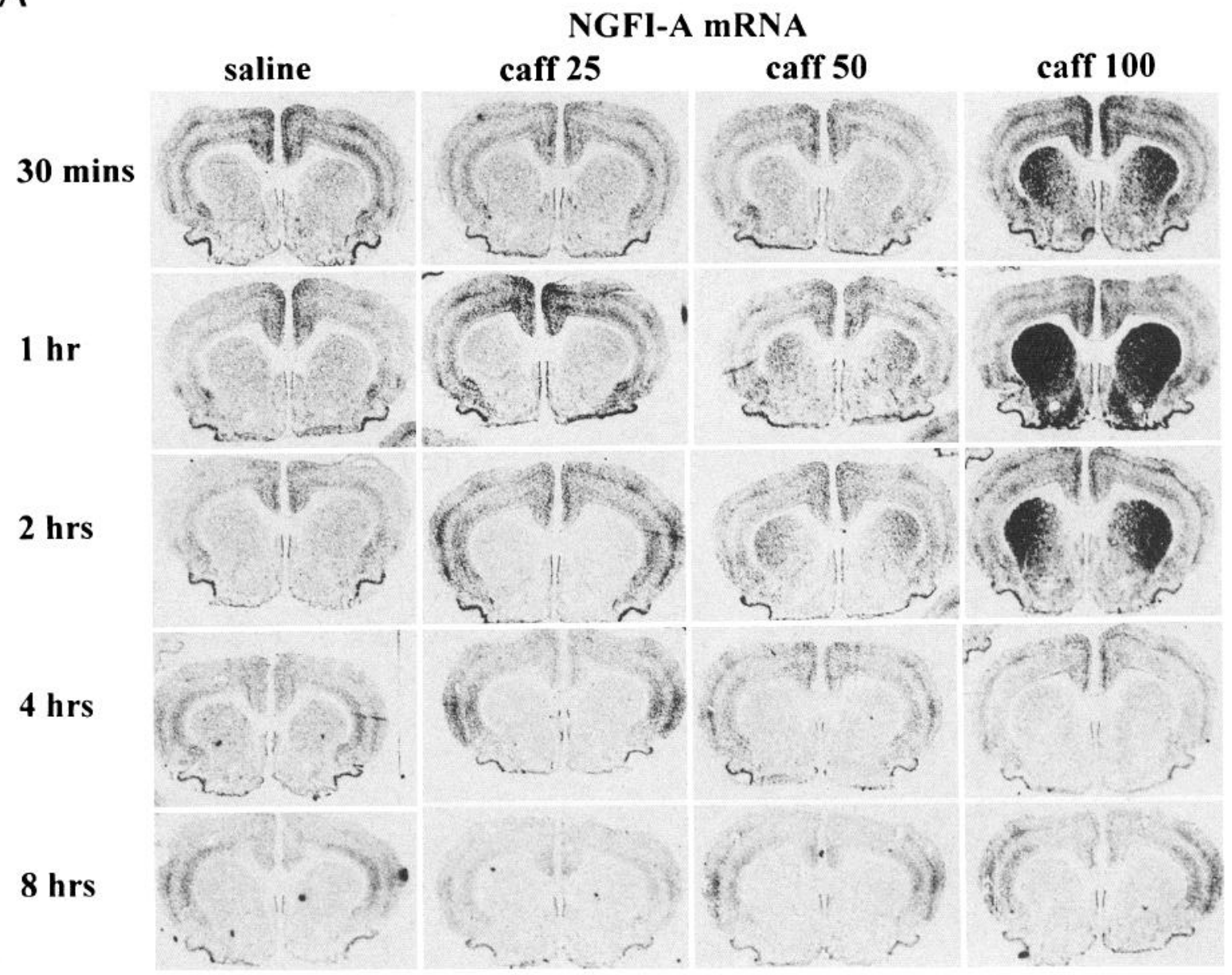

B

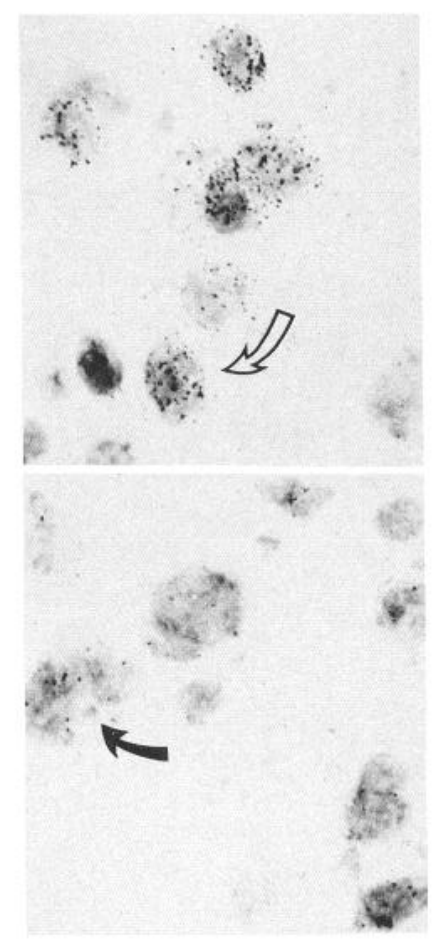


A
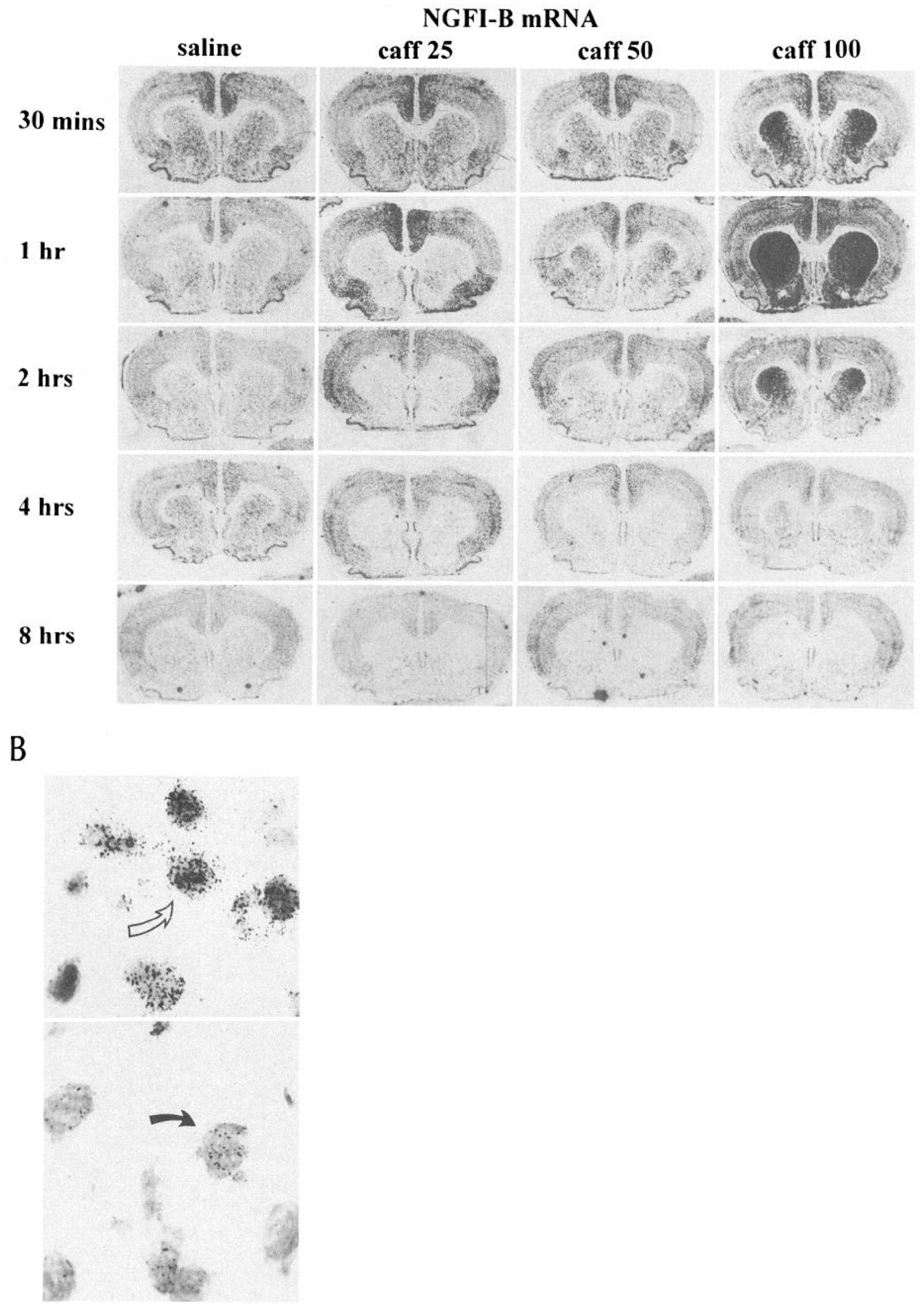

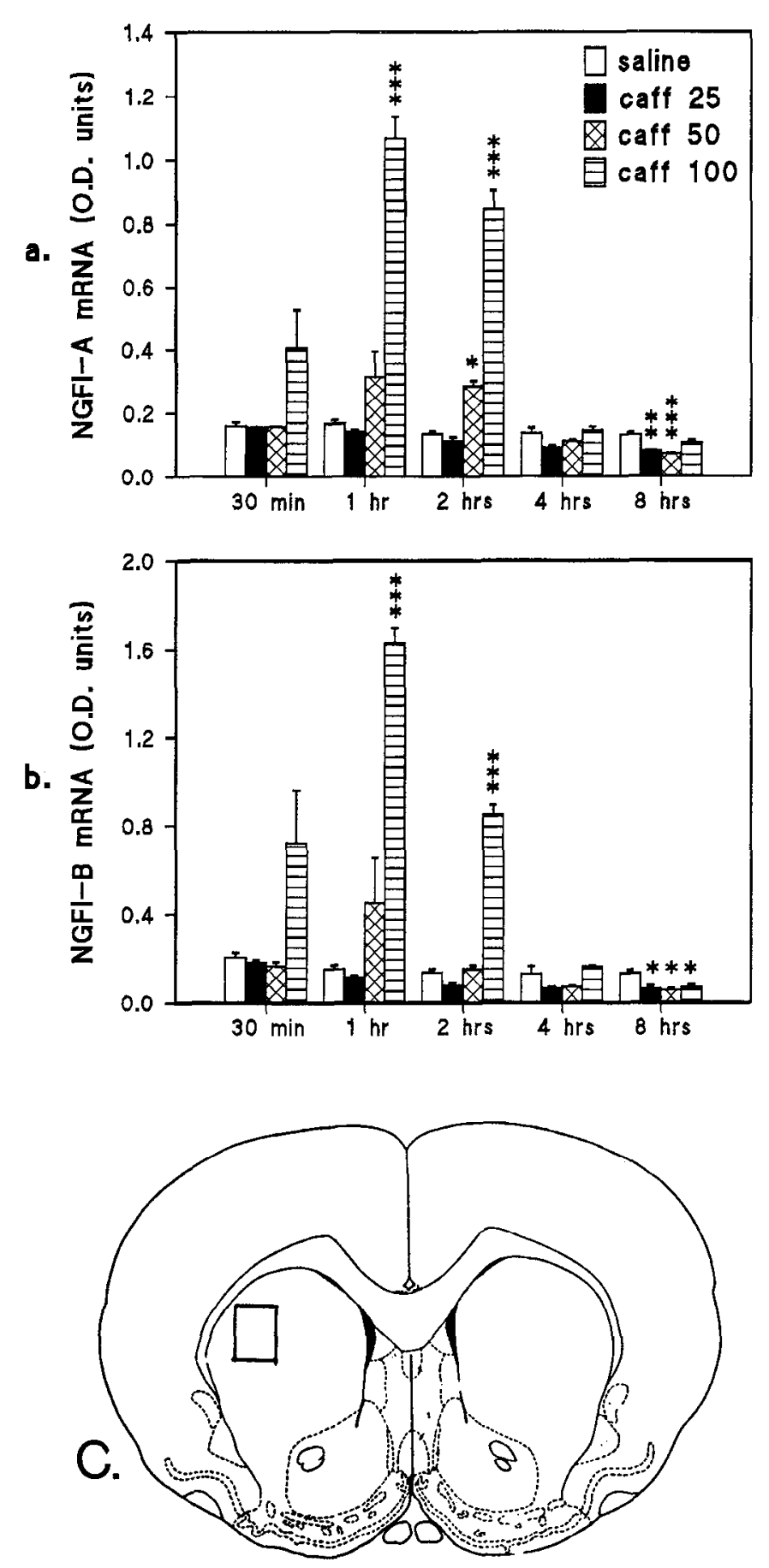

Figure 3. Time-course of the expression of NGFI-A mRNA $(a)$ and NGFI-B mRNA $(b)$ in the dorsolateral part of caudate-putamen $(c)$ after injection of saline or caffeine in the doses given in the figure. The results are given as the mean $\pm \mathrm{SEM}$, from three animals in each group. $*, P<0.05$; **, $P<0.01$; ***,$P<0.001$; each versus corresponding saline-treated.

(Moratalla et al., 1992) the NGFI-A mRNA signal in salinetreated rats appeared to be homogeneously distributed within striatum (Fig. 1a). In agreement with several previous reports (see Hughes and Dragunow, 1995) that even mild stress, such as injection of saline, can induce a small increase in immediate early genes, the level of NGFI-A (Figs. $1 a, 3 a$ ) and NGFI-B (Figs. $2 a, 3 b$ ) tended to be higher at $30 \mathrm{~min}$ after saline injection than $8 \mathrm{hr}$ thereafter. This effect was smaller in the caudate-pu- tamen (Fig. 3), particularly in its dorsolateral part, where most measurements were made (Fig. $3 c$ ) than in cingulate cortex (Fig. 4). On the average, the effect was small however. In salineinjected animals, approximately one-third of the cells that expressed either preproenkephalin mRNA or preprotachykinin mRNA also showed labeling of NGFI-A mRNA (Table 1). At all examined time points, NGFI-A mRNA expression in caudateputamen in rats treated with caffeine $(25 \mathrm{mg} / \mathrm{kg})$ tended to be lower than control. In the first experiment, a significant decrease was observed only after $8 \mathrm{hr}$ (Figs. $1 a, 3 a$ ). In the second experiment, a significant decrease was found also 4 hr after treatment (see Figs. 6, 9a). The difference was probably due to the difference in the number of animals used in the two experiments. We used emulsion in situ hybridization to examine if the decrease in NGFI-A mRNA was seen in cells expressing preproenkephalin or preprotachykinin mRNA. The results show a significant fall in enkephalin-containing neurons but no change in cells expressing substance $\mathrm{P}$ (Table 1, Fig. $5 a, b$ ). In rats treated with a higher dose of caffeine $(50 \mathrm{mg} / \mathrm{kg})$ a significant induction of NGFI-A mRNA expression was found in the lateral part of caudate-putamen $2 \mathrm{hr}$ following injection (Figs. 1a, 3a). Thereafter, the NGFI-A mRNA signal was reduced to a level significantly below the control. Following administration of caffeine at the highest dose examined $(100 \mathrm{mg} / \mathrm{kg})$ a rapid induction of NGFI-A mRNA was seen throughout the caudate-putamen (Figs. 1a, 3a). The induction peaked $1 \mathrm{hr}$ after treatment and remained significantly elevated also after $2 \mathrm{hr}$. At the cellular level $90 \%$ of 103 examined neuron-like cells were labeled one hour after treatment (Fig. 1b). An induction was also seen in nucleus accumbens (Fig. 1a).

Effect of a single injection of caffeine on the expression of $N G F I-B m R N A$ in striatum. In saline-treated rats the expression of NGFI-B mRNA appeared to be somewhat more pronounced in the ventromedial part of caudate-putamen than in the dorsolateral (Fig. 2a). Rats treated with the lowest dose of caffeine (25 $\mathrm{mg} / \mathrm{kg}$ ) showed a significantly decreased expression of NGFI-B mRNA in caudate-putamen only after $8 \mathrm{hr}$ in the first experiment, but also after $4 \mathrm{hr}$ in the second (Figs, $2 a, 3 b, 7$, $9 b)$. The effects of caffeine $(50 \mathrm{mg} / \mathrm{kg})$ on NGFI-B mRNA expression were not so marked, but a significant reduction after 8 hr was found (Figs, $2 a, 3 b$ ). The highest dose of caffeine (100 $\mathrm{mg} / \mathrm{kg}$ ) caused a highly significant induction of NGFI-B mRNA signal throughout caudate-putamen and nucleus accumbens (Figs. $2 a, 3 b$ ). In agreement with the data for NGFI-A mRNA expression, the induction peaked $1 \mathrm{hr}$ following administration and at this time point $89 \%$ of 106 examined neuron-like cells in the lateral part of striatum showed an increased signal (Fig. $2 b$ ). Eight hours posttreatment the expression was significantly rcduced compared to the control level.

Effect of a single injection of caffeine on the expression of $N G F I-A$ and NGFI-B mRNA in cortex. It has previously been reported that a single injection of saline rapidly induces expression of c-fos in piriform and cingulate cortex (Sharp et al., 1991). We detected a similar induction of NGFI-A mRNA and NGFI-B mRNA by saline (Fig. $4 a, b)$. Rats treated with caffeine $(25 \mathrm{mg}$ / $\mathrm{kg}$ or $100 \mathrm{mg} / \mathrm{kg}$ ) showed a significantly higher expression of NGFI-B mRNA in the cingulate cortcx $1 \mathrm{hr}$ after administration. Treatment with saline did not alter the basal expression of NGFI-A mRNA and NGFI-B mRNA in the parietal cortex (Fig. $4 c, d)$, but caffeine $(25 \mathrm{mg} / \mathrm{kg})$ significantly increased the expression of both genes 2 and 4 hr posttreatment. No significant 

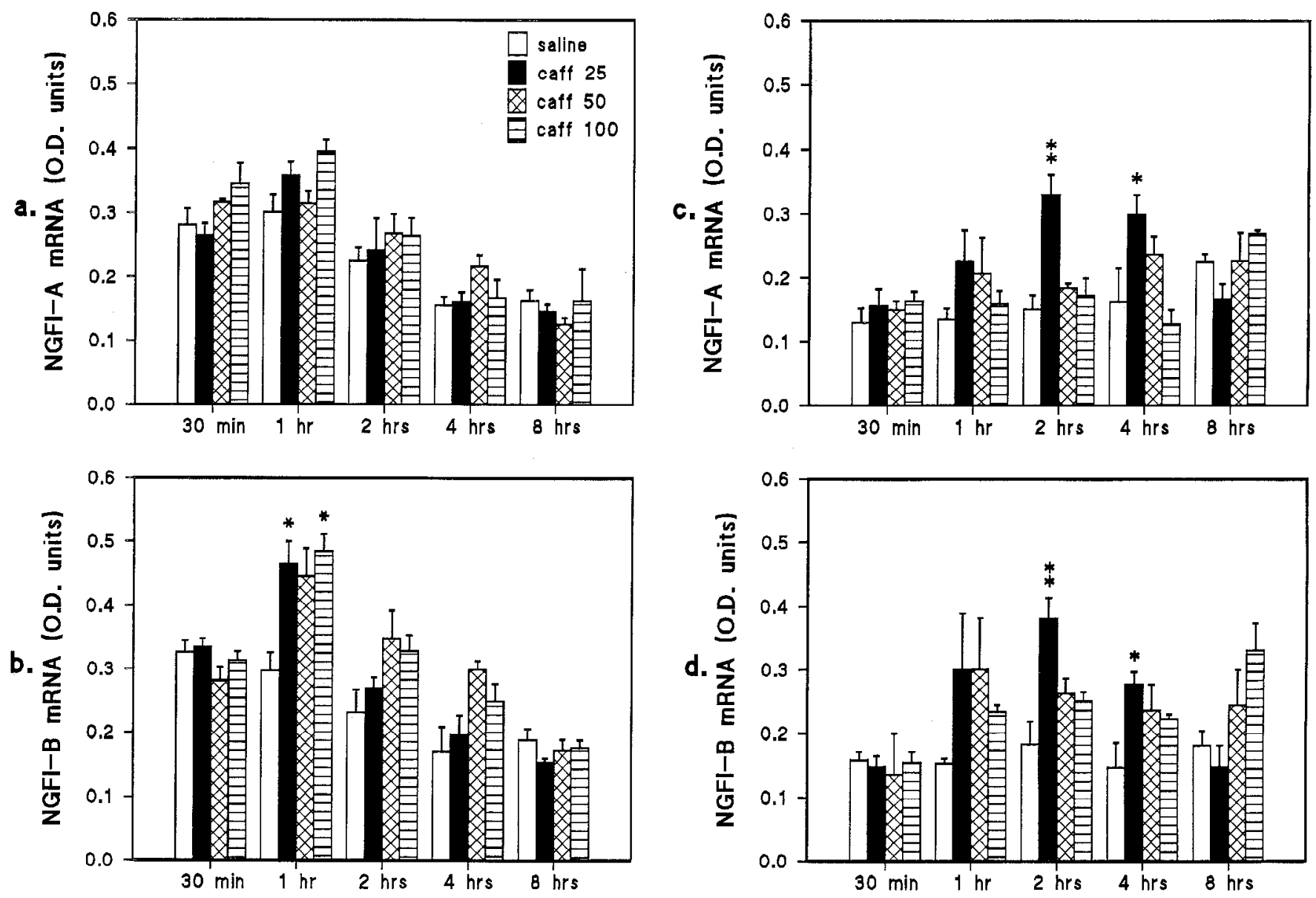

Figure 4. Time-course of the expression of mRNA for NGFI-A $(a, c)$ and NGFI-B $(b, d)$ in the cingulate cortex $(a, b)$ and in the parietal cortex $(c, d)$. The results are given as mean $\pm \mathrm{SEM}$, from three animals in each group. $*, P<0.05$; **, $P<0.01 ; * * *, P<0.001 ;$ each versus corresponding saline-treated.

Table 1. Proportion of neuron-like cells that are positive or negative for preproenkephalin mRNA (ENK), substance P mRNA (SP), and NGFI-A mRNA in the dorsolateral part of caudateputamen

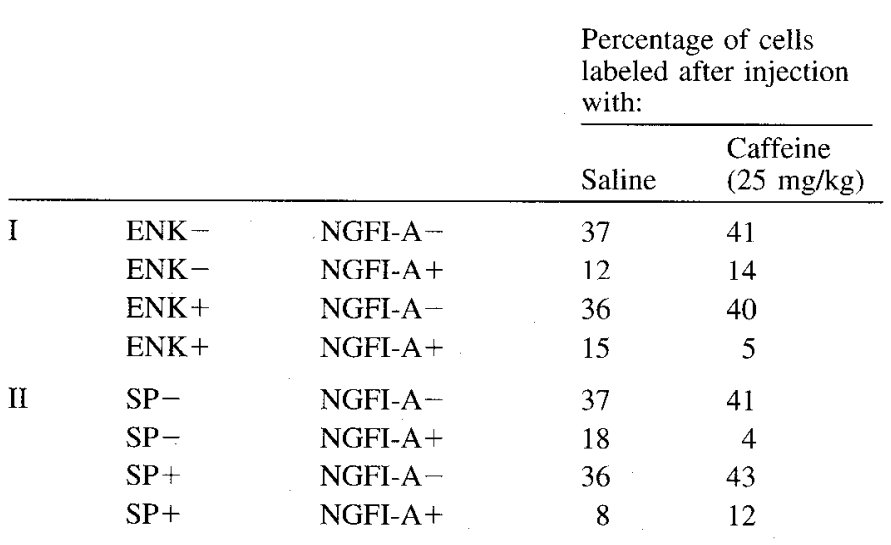

Two hundred thirty cells were studied to obtain these values. The data were subjected to a $\chi^{2}$ analysis to determine if caffeine produced any significant change in the labeling pattern. The results were pooled so that neurons laheled with NGFI-A and either labeled with ENK or unlabeled with SP were considered to constitute one population, and neurons labeled with NGFI-A and either unlabeled with ENK or labeled with SP constituted the other population. The results show a significant difference $(P<0.013$ by Yates test) or a highly significant difference $(P<0.0015$ by Fischer's exact test $)$ in the former but not in the latter population. alterations were detected in rats treated with the higher doses of caffeine.

Effects of quinpirole and raclopride, alone or in combination with caffeine, on the expression of $m R N A$ for NGFI-A, NGFI-B, and jun $B$. Since rats treated with caffeine $(25 \mathrm{mg} / \mathrm{kg})$ demonstrated a lower signal for NGFI-A mRNA and NGFI-B mRNA than did control rats, we wanted to examine whether such an effect could be observed for another, structurally different, immediate early gene, $j u n \mathrm{~B}$. As seen in Figures 8 and $9 c$ caffeine did decrease the expression of jun B mRNA, but the decrease was less marked than that observed in mRNA for NGFI-A and NGFI-B.

The results therefore suggest that a low dose of caffeine was able to reduce the expression of mRNA for three structurally very different immediate early genes. The finding that this effect, at least in the case of NGFI-A mRNA expression, was confined to the dopamine $\mathrm{D}_{2}$, receptor-expressing striatopallidal neurons also suggests a link to $\mathrm{D}_{2}$ receptor transmission. We therefore examined the effect of the dopamine $\mathrm{D}_{2}$ agonist quinpirole. Four hours after the administration of quinpirole in a dose of either 1 or $3 \mathrm{mg} / \mathrm{kg}$, there was a clear-cut and highly significant decrease in the expression of NGFI-A mRNA and NGFI-B mRNA (Figs. 6, 7, 9a,b). Quinpirole $(1 \mathrm{mg} / \mathrm{kg})$ and caffeine $(25 \mathrm{mg} / \mathrm{kg})$ did not show any clear additive effect. On the other hand, for jun $\mathrm{B}$, only the highest dose of quinpirole caused a significant reduction (Fig. 9c). Animals with the dopamine $\mathrm{D}_{2}$ antagonist 

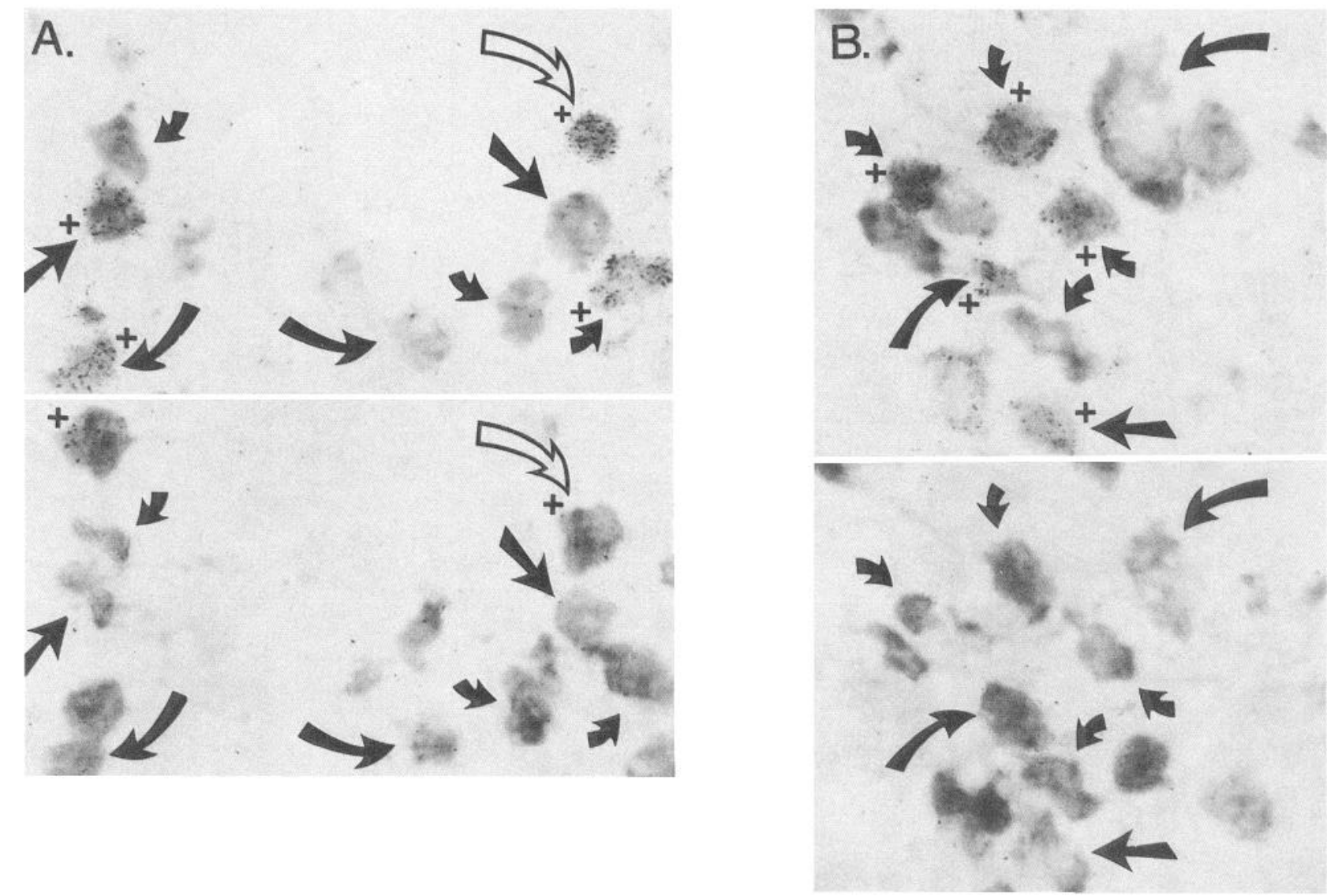

Figure 5. Emulsion autoradiograms from the lateral part of rostral caudate-putamen of rats treated with saline $(a)$ or caffeine $25 \mathrm{mg} / \mathrm{kg}(b)$ and sacrificed $4 \mathrm{hr}$ posttreatment. Consecutive $5 \mu \mathrm{m}$ sections were hybridized using probes for preproenkephalin mRNA (top) and NGFI-A mRNA (bottom). Arrows indicate counted neurons; open arrows indicate a neuron considered to express both genes. Plus signs indicate neurons considered to be labeled.

raclopride $(2 \mathrm{mg} / \mathrm{kg})$ and sacrificed after $4 \mathrm{hr}$ showed an expression of mRNA for NGFI-A, NGFI-B and jun B that was at the same level as that seen in saline-treated rats (Figs. 6, 7, 9ac). However, when raclopride injections were combined with caffeine $(25 \mathrm{mg} / \mathrm{kg})$ the expression of all three genes was significantly reduced compared to the expression following raclopride alone.

Behavioral study. We finally wanted to examine whether there was a relationship between the biphasic effects of caffeine on gene expression and changes in motor activity. As seen in Figure 10 , rats injected with saline exhibited a very transient increase in both horizontal and vertical activity counts, indicating increased forward locomotion as well as rearing. Rats treated with the lowest dose of caffeine $(25 \mathrm{mg} / \mathrm{kg})$ showed significantly greater locomotor activity than did saline-treated rats during the first $3 \mathrm{hr}$ after administration (Fig. 10a). Caffeine-treated (25 $\mathrm{mg} / \mathrm{kg}$ ) rats also exhibited significantly more rearing than salinetreated rats, 1, 3, and $4 \mathrm{hr}$ posttreatment (Fig. 10b).

Following administration of $50 \mathrm{mg} / \mathrm{kg}$ caffeine there was a smaller but more sustained increase in horizontal activity compared to that seen after $25 \mathrm{mg} / \mathrm{kg}$ caffeine (Fig. 10a). A tendency to an increase in vertical activity was also seen, but this did not reach statistic significance (Fig. 10b). The highest dose of caffeine $(100 \mathrm{mg} / \mathrm{kg})$ caused a significant reduction of both rearing and locomotion at the first hour posttreatment (Fig. 10a,b). How- ever, there was a tendency for the rats treated with $100 \mathrm{mg} / \mathrm{kg}$ to be more active than saline-treated at the later time-points.

\section{Discussion}

The main finding of the present study is that caffeine in a dose that causes an increase in locomotor activity, causes a significant reduction in the expression of NGFI-A mRNA and NGFI-B mRNA in striatum. This decrease seemed to occur mostly in striatopallidal neurons and was mimicked by a dopamine $\mathrm{D}_{2}$ agonist. By contrast, the highest dose of caffeine, which produces a decrease in locomotor behavior, caused an acute induction of the immediate early genes. In the parietal cortex only the lowest dose of caffeine significantly altered the expression of the examined immediate early genes.

Behavioral effects of caffeine are biphasic (for review, see Daly, 1993; Fredholm, 1995). At lower doses, caffeine increases motor activity (e.g., Garrett and Holtzman, 1994b; present data) and causes contralateral rotation in animals with unilateral 6-OH-dopamine lesions of the nigrostriatal dopamine pathway (Fuxe and Ungerstedt, 1974; Fredholm et al., 1976; Josselyn and Beninger, 1991). This motor stimulation is generalized with other psychostimulants such as cocaine and amphetamine in rats trained to discriminate between saline and a low dose of caffeine (Mumford and Holtzman, 1991). On the other hand, higher doses of caffeine do not increase motor activity (e.g., Garrett and 


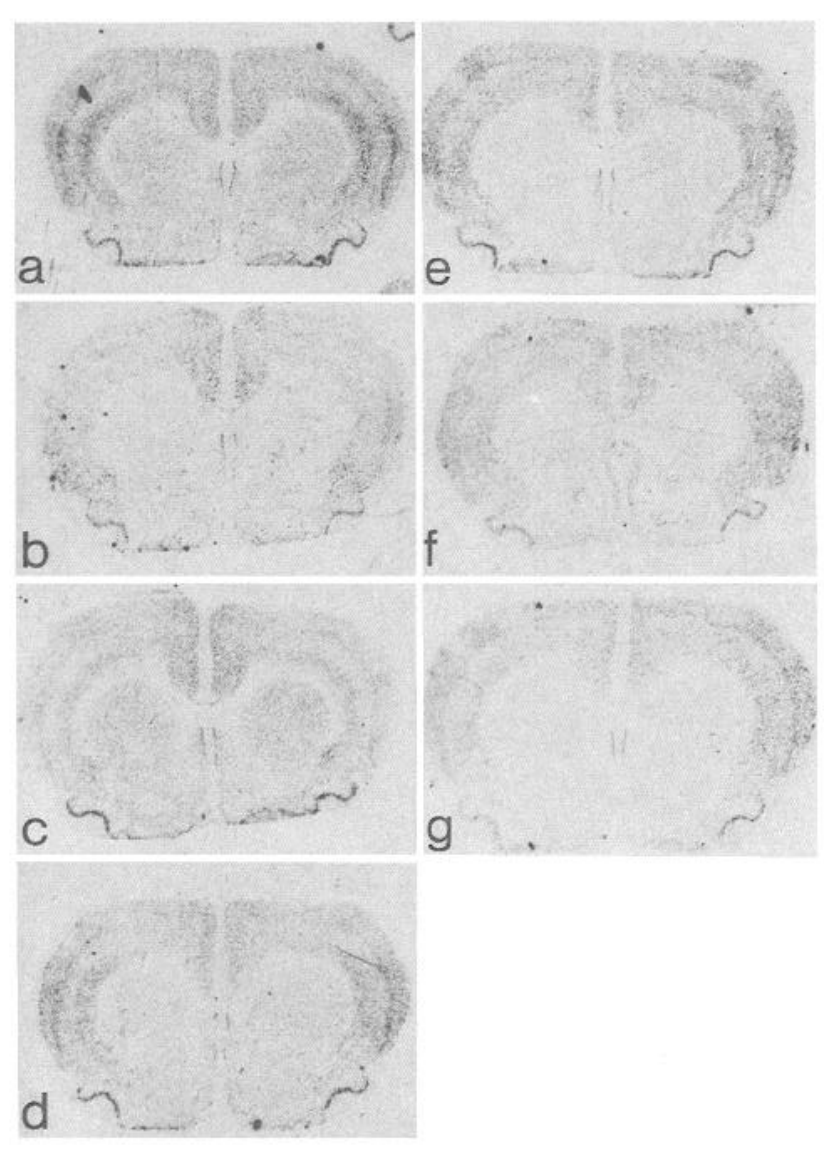

Figure 6. In situ hybridization autoradiograms showing the distribution of NGFI-A mRNA expression in coronal sections of brain of rats treated with saline $(a)$, caffeine $25 \mathrm{mg} / \mathrm{kg}(b)$, raclopride $2 \mathrm{mg} / \mathrm{kg}(c)$, raclopride $2 \mathrm{mg} / \mathrm{kg}$ plus caffeine $25 \mathrm{mg} / \mathrm{kg}(d)$, quinpirole $3 \mathrm{mg} / \mathrm{kg}(e)$, quinpirole $1 \mathrm{mg} / \mathrm{kg}(f)$, or quinpirole plus caffeine $25 \mathrm{mg} / \mathrm{kg}(g)$ and sacrificed after $4 \mathrm{hr}$.

Holtzman, 1994b; present data) and are generalized only with the caffeine metabolite theophylline (Mumford and Holtzman, 1991). In humans, low doses of caffeine are reported as stimulating, whereas high doses induce dysphoria (Griffiths and Woodson, 1988; Daly, 1993).

There are some results that point to a neurochemical correlates to these behavioral actions of caffeine. Thus, caffeine and theophylline, in high doses, are known to affect dopamine and noradrenaline turnover in several brain regions (Waldeck, 1971; Karasawa et al., 1976; Govoni et al., 1984; Fredholm, 1985). The effects are small, however, and it has not been proven that there is a central site of action. Since the doses given have been high, these changes in monoamine turnover may reflect depressant rather than stimulant doses of caffeine. The same may be said about previous results on changes in gene expression.

Immediate early genes act as indicators of activated neuronal systems (Sagar et al., 1988), and their expression may thus be used to study acute effects of caffeine. We and others have reported that a single injection of caffeine at doses between 50 and $100 \mathrm{mg} / \mathrm{kg}$ can upregulate expression of mRNA for the immediate early genes c-fos, jun B and c-jun (Nakajima et al., 1989; Johansson et al., 1993a; Svenningsson et al., 1995). This induction is followed by increased levels of mRNA for enkephalin and dynorphin in the same regions (Svenningsson et al., 1995, and own unpublished observations).

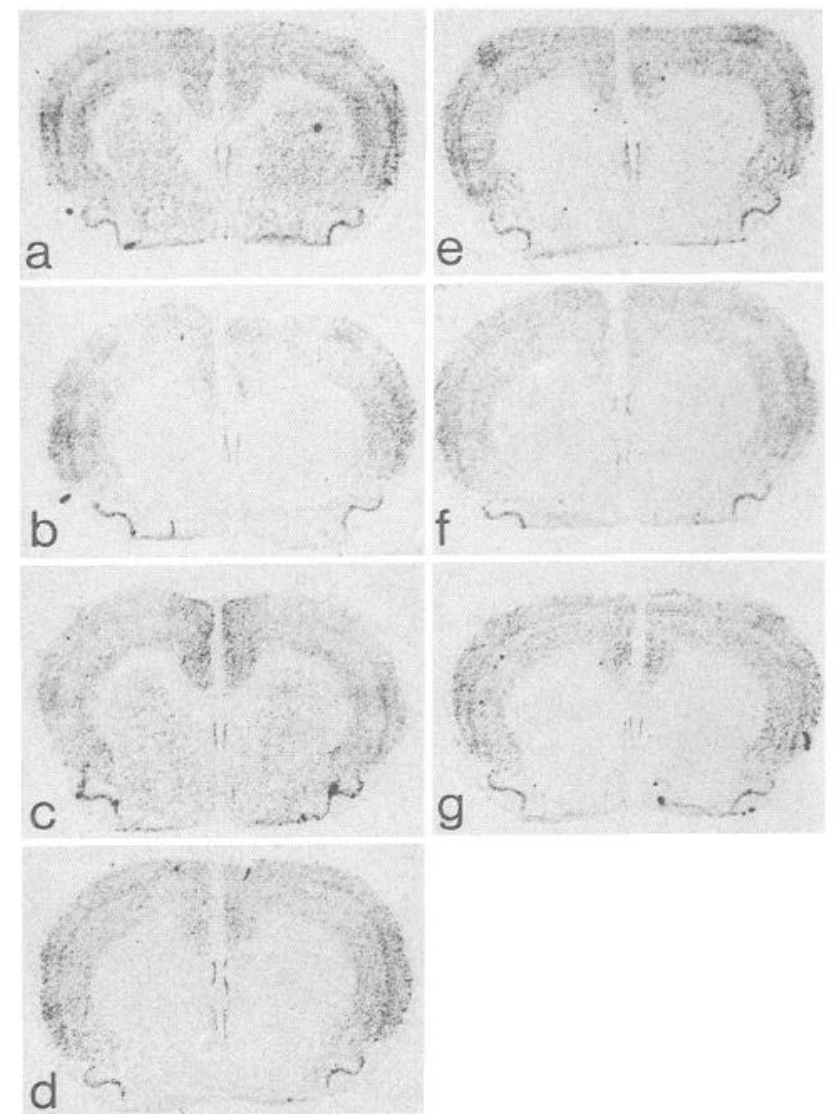

Figure 7. In situ hybridization autoradiograms showing the distribution of NGFI-B mRNA expression in coronal sections of brain of rats treated with saline $(a)$, caffeine $25 \mathrm{mg} / \mathrm{kg}(b)$, raclopride $2 \mathrm{mg} / \mathrm{kg}(c)$, raclopride $2 \mathrm{mg} / \mathrm{kg}$ plus caffeine $25 \mathrm{mg} / \mathrm{kg}(d)$, quinpirole $3 \mathrm{mg} / \mathrm{kg}(e)$, quinpirole $1 \mathrm{mg} / \mathrm{kg}(f)$, or quinpirole plus caffeine $25 \mathrm{mg} / \mathrm{kg}(\mathrm{g})$ and sacrificed after $4 \mathrm{hr}$.

The present finding that caffeine $(25 \mathrm{mg} / \mathrm{kg})$ decreased the expression of mRNA for NGFI-A and NGFI-B in striatum may be the first evidence for neurochemical changes induced by clearly stimulant doses of caffeine. As noted in the introduction, the only known biochemical actions of caffeine in the concentrations reached following administration of doses of caffeine similar to normal human consumption is blockade of adenosine receptors. Since the effect was most clear-cut in the striatum, where $A_{2 A}$ receptors are abundant, the data suggest that antagonism at adenosine $\mathrm{A}_{2 \mathrm{~A}}$ receptors plays an important role in mediating the effects of caffeine. This is further supported by the finding that the caffeine-induced changes were located specifically to the striatopallidal neurons, which are the ones expressing $\mathrm{A}_{2 \mathrm{~A}}$ receptors in high abundance. An important effect of methylxanthines on these neurons in vivo was recently shown in microdialysis experiments (Ferré et al., 1993). It was shown that a reduction of extracellular GABA in globus pallidus could be brought about by intrastriatal infusion of $\mathrm{D}_{2}$ agonist. The effect of the $\mathrm{D}_{2}$ agonist could be counteracted by an $\mathrm{A}_{2 \mathrm{~A}}$ agonist. Furthermore, the methylxanthine theophylline, which shares with caffeine the ability to block $A_{2 A}$ receptors could per se decrease the extracellular levels of GABA in globus pallidus (Ferré et al., 1993).

Thus, there is a parallelism between caffeine-induced increase in locomotion and a decrease in the expression of the mRNA 


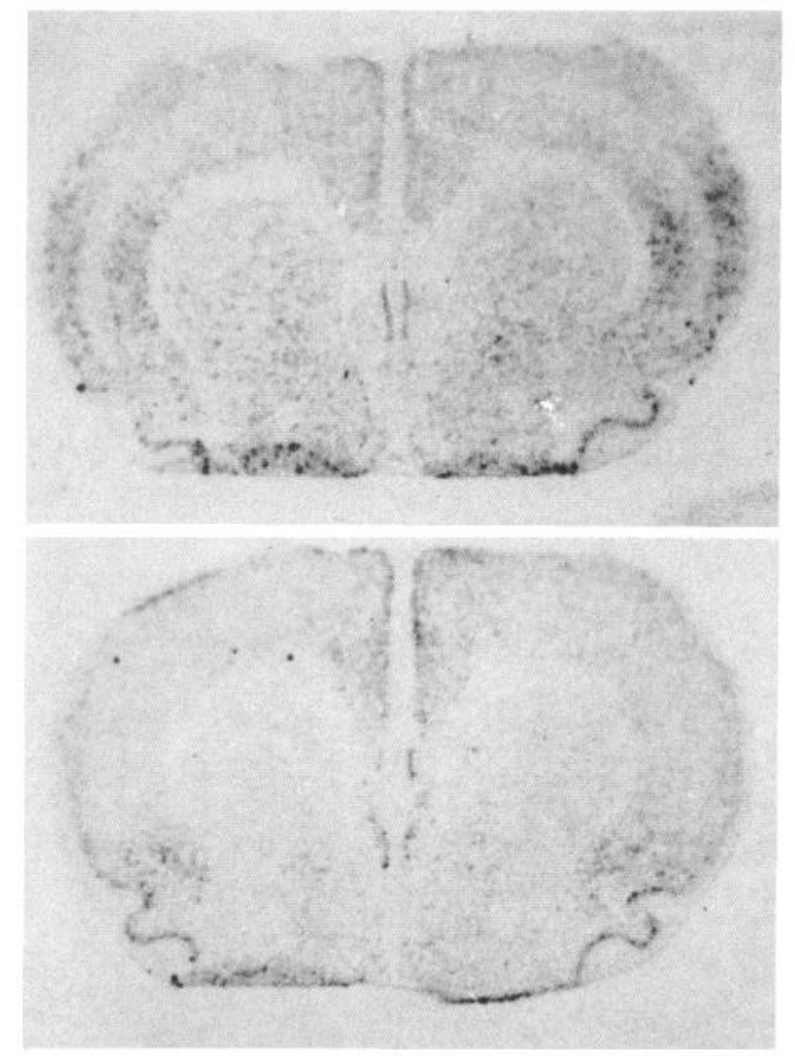

Figure 8. In situ hybridization autoradiograms showing the distribution of jun B mRNA expression in coronal sections of striatum of rats treated with saline (top) or caffeine $25 \mathrm{mg} / \mathrm{kg}$ (bottom) and sacrificed after $4 \mathrm{hr}$.

for some immediate early genes in the striatum. The parallelism does not imply a direct causal relationship. Clearly the fall in mRNA cannot be the cause of the altered motor behavior since the latter occurred very rapidly. Conversely, the alteration in locomotor behavior is unlikely to cause the change in mRNA expression. Thus, other drugs such as amphetamine cause an increase in locomotor behavior and an increase in the expression of mRNA for NGFI-A (Moratalla et al., 1992). The possibility exists, however, that the parallelism may be due to the fact that a single mechanism is the cause of a change both in mRNA and in locomotion after caffeine.

There is reason to believe that a reduction of intracellular levels of cAMP is important for the observed decrease in the expression of the immediate early genes, since both NGFI-A and NGFI-B have CRE-like binding sites in their $5^{\prime}$ flanking sequence (Tsai-Morris et al., 1988; Watson and Milbrandt, 1989; Sheng and Greenberg, 1990). $\mathrm{A}_{2 \mathrm{~A}}$ receptors are coupled to G-proteins that activate adenylyl cyclase (Fredholm, 1977; Fredholm et al., 1994). By antagonizing the actions of adenosine at these receptors, caffeine would decrease intracellular cAMP levels. In addition, by preventing $\mathrm{A}_{2 \mathrm{~A}}$ receptor agonists from decreasing the affinity of dopamine at $\mathrm{D}_{2}$ receptors (see Ferré et al., 1992), caffeine could increase the dopaminergic transmission via $D_{2}$ receptors. $D_{2}$ receptors are coupled to $G_{1}$-proteins (Senogles, 1994), and decrease the levels of cAMP. It should be pointed out that a $D_{2}$ agonist will be able to depress cAMP formation only if there is a high basal rate of cAMP generation. Adenosine acting on $\mathrm{A}_{2 \mathrm{~A}}$ receptors is a probable mediator of such basal cAMP generation (see Fig. 11).
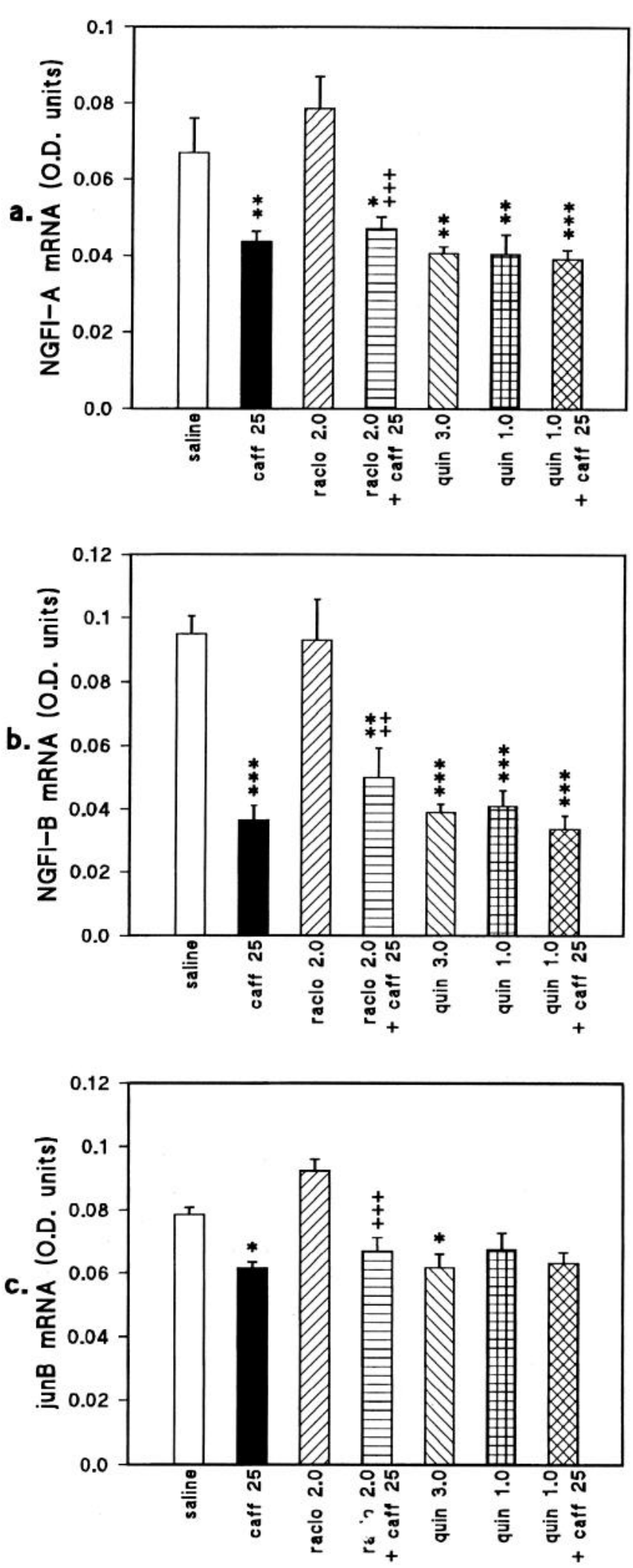

Figure 9. Expression of NGFI-A mRNA (a), NGFI-B mRNA (b), and jun B mRNA $(c)$ in the dorsolateral part of caudate-putamen $4 \mathrm{hr}$ after treatment with indicated drugs. The results are given as the mean \pm SEM, from six animals in each group. ${ }^{*}, P<0.05$; **, $P<0.01$; ***, $P<0.001$; each versus corresponding saline-treated.,$++ P<0.01 ;$ and,$+++ P<0.001$, each versus raclopride-treated alone. 


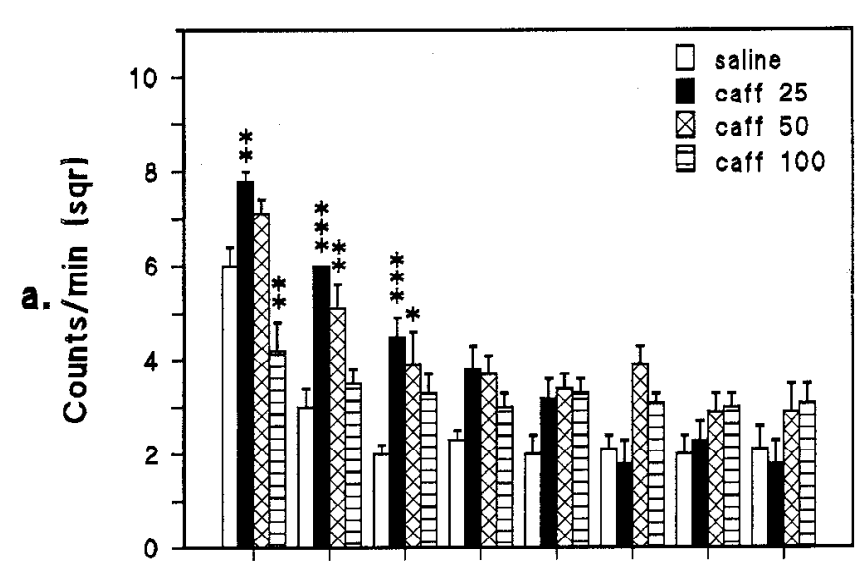

1 hr 2 hrs 3 hrs 4 hrs 5 hrs 6 hrs 7 hrs 8 hrs

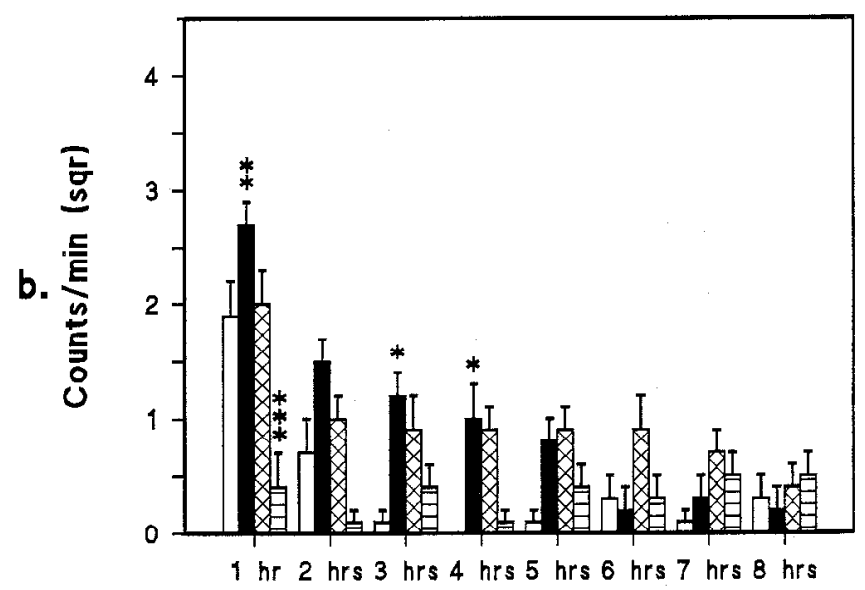

Figure 10. Time-course of horizontal $(a)$ and vertical (b) activity in rats treated with a single injection of saline or caffeine $(25 \mathrm{mg} / \mathrm{kg}, 50$ $\mathrm{mg} / \mathrm{kg}$, and $100 \mathrm{mg} / \mathrm{kg}$ ). The results are given as the mean $\pm \mathrm{SEM}$, from eight animals in each group. *, $P<0.05 ; * *, P<0.01 ; * * *, P$ $<0.001$; each versus corresponding saline-treated.
Bidirectional changes in gene expression following low and high doses of caffeine were also found for jun B. The basal expression of jun B is known to be relatively high in striatum (Mellström et al., 1991) and we have previously reported that the expression of this immediate early gene increases markedly following administration of a high dose of caffeine (Svenningsson et al., 1995). In the present study we observed a weak, but significant, reduction of jun B in caudate-putamen following administration of caffeine $(25 \mathrm{mg} / \mathrm{kg})$. Interestingly, it has been reported that cAMP can regulate also the expression of jun $\mathrm{B}$ (de Groot et al., 1991).

Our working hypothesis is illustrated in Figure 11. It is assumed that the level of cAMP is important to determine the expression of mRNA for NGFI-A, NGFI-B, and Jun B in striatopallidal neurons. It is further assumed that the rate of cAMP production is importantly controlled by adenosine, acting on $\mathrm{A}_{2 \mathrm{~A}}$ receptors to stimulate adenylyl cyclase, and by dopamine, acting on $D_{2}$ receptors to inhibit the enzyme. In agreement with this basic hypothesis, the $D_{2}$ receptor agonist quinpirole was found to induce a marked reduction of the expression of mRNA for NGFI-A and NGFI-B. Quinpirole does not alter the expression of c-fos (Paul et al., 1992) unless c-fos expression is enhanced, for example, by reserpine treatment (Cole and Di Figlia, 1994). Interestingly, caffeine $(25 \mathrm{mg} / \mathrm{kg}$ ) had an effect of equal magnitude, and its effect was not clearly additive to that of quinpirole. Since the effect of caffeine was confined to the striatopallidal neurons, the data suggest that these neurons are the target also for quinpirole. It is known that neuroleptic drugs with $D_{2}$ antagonistic properties cause a rapid increase in immediate early gene expression; this effect has been atributed to a removal of an inhibitory $\mathrm{D}_{2}$ receptor tone (Robertson et al., 1992; Merchant and Dorsa, 1993). In the present study, the $\mathrm{D}_{2}$ receptor antagonist raclopride was given $4 \mathrm{hr}$ before sacrifice, and then there was no significant effect of the antagonist per se. Raclopride did not inhibit the depressant effect of caffeine given simultaneously with raclopride. These findings can be explained if adenosine
Caffeine

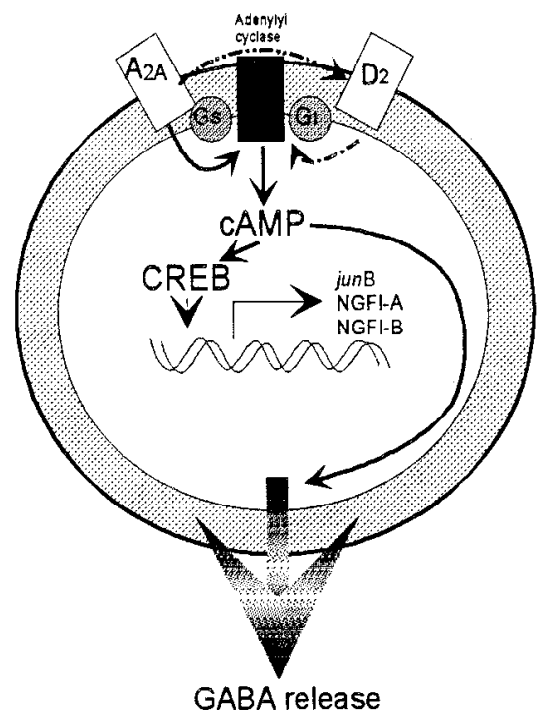

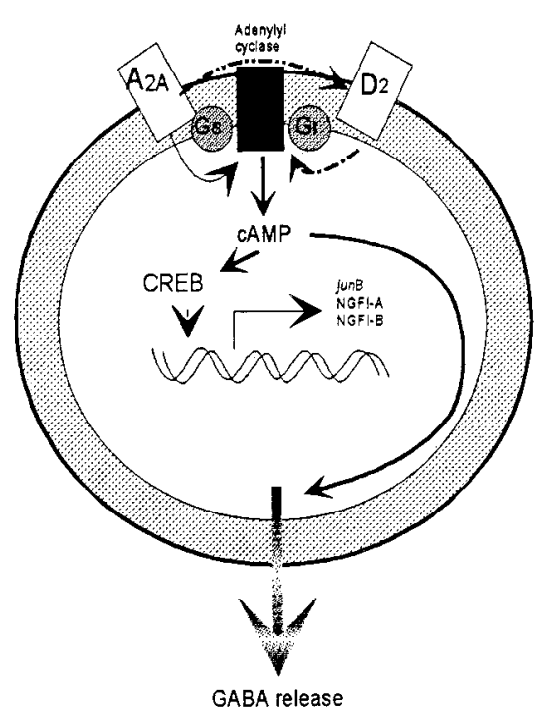

Figure 11. Schematic representation of a possible mechanism by which caffeine and quinpirole could alter the expression of mRNA for NGFI-A and NGFI-B through alterations in CAMP acting on CRE element. Raclopride would have an effect opposite to that of quinpirole. It is also indicated that there are parallel changes in the release of GABA. Whether the GABA release is related to cAMP is, however, not known. For further details see text. 
and dopamine are both tonically active at their respective receptors. Thus, when dopamine receptors are blocked with raclopride, the stimulatory effect of ademusine is unhampered, leading to a transient increase in the immediate early gene expression; when the adenosine receptors are also blocked, gene expression is brought down to essentially normal levels. The finding is less easy to explain if it is assumed that the major effect of adenosine $A_{2 A}$ receptor stimulation is to regulate signaling via the $D_{2}$ receptors. Thus, we have to assume that adenosine plays an important role in regulating gene expression in striatopallidal neurons that is independent of its established ability to influence the affinity of dopamine as an agonist at $\mathrm{D}_{2}$ receptors (Ferré et al., 1992). The scheme in Figure 11 also indicates that GABA release in the pallidum may be regulated by adenosine and dopamine in opposite directions, perhaps via cAMP, but there is little or no direct support for this proposal.

Unlike the effects of low doses of caffeine, the effects of higher doses are probably not that closely related to changes in cAMP. Caffeine, at high concentrations, can induce expression of c-jun (Svenningsson et al., 1995), which lacks cAMP responsive elements in its 5' flanking sequence (Angel et al., 1988). It is important to point out that, in contrast to the decrease in the expression of immediate early genes seen after low doses, which occurs mainly in striatopallidal neurons, the increase after higher doses occurs in both types of medium-sized spiny neurons (Johansson et al., 1993a; Svenningsson et al., 1995; this study). We recently found an inhibition of the caffeine-induced expression of mRNA for NGFI-A, and c-fos in caudate-putamen following pretreatment with NMDA receptor antagonists (Svenningsson et al., 1996). This indicates that caffeine at high doses causes increased glutamate release in caudate-putamen. At least some corticostriatal neurons express presynaptic $\mathrm{A}_{1}$ receptors (Alexander and Reddington, 1989), and it is known that adenosine via $A_{1}$ receptors can inhibit glutamate release (Fredholm and Dunwiddic, 1988). Thereforc, some of the effects of higher doses of caffeine might be explained by an antagonism at these presynaptic $A_{1}$ receptors and thereby increased glutamatergic transmission followed by higher intracellular levels of calcium.

The finding that caffeine $(25 \mathrm{mg} / \mathrm{kg}$ ) altered the expression of NGFI-A and NGFI-B mRNA in cingulate and, especially, parietal cortex is unlikely to be a direct consequence of antagonism al cortical adenosine $A_{2 A}$ receptors. Although $A_{2 A}$ receptors have been detected in cortical regions their abundance is low (Johansson et al., 1993b). There are two other more likely explanations. The increase in the cortex may be a secondary consequence of a primary effect on $A_{2 \mathrm{~A}}$ receptors in the striatum. Thus, it has been shown that the $\mathrm{D}_{2}$ receptor agonist quinpirole, which has effects similar to those of caffeine, causes an increase in c-Fos immunoreactivity in some cortical regions in doses that do not affect striatal c-Fos (Paul et al., 1992). It was proposed that this was a consequence of a primary reduction in the firing of striatopallidal neurons. The other possibility is that adenosine $A_{1}$ receptors tonically decrease the release of transmitters, via their known presynaptic effects (Fredholm and Dunwiddie, 1988). By blocking these receptors, caffeine might increase the release of a transmitter, perhaps glutamate, that is able to increase immediate early gene expression. Studies with receptorselective adenosine antagonists are required to discriminate between these possibilities.

Repeated administration of low and high doses of caffeine leads to a development of tolerance to its behavioral effects (Holtzman and Finn, 1988; Nikodijeviç et al., 1993). There is also a decreased susceptibility to seizures and ischemic brain damage (Georgiev et al., 1993; Bona et al., 1995). Several studies have shown that chronic treatment with caffeine causes an upregulation of adenosine $A_{1}$ receptors (Fredholm, 1982; Johansson et al., 1993a; Shi et al., 1993). There is also evidence that receptors for other transmitters, especially GABA and $\mathrm{ACh}$, as well as $\mathrm{G}_{\mathrm{i}}$-proteins are affected (Ramkumar et al., 1988; Shi et al., 1993). Interestingly, both NGFI-A and NGFI-B proteins can bind specifically to DNA (Christy and Nathans, 1989; Wilson et al., 1991) and act as transcription factors. It has, for example, been shown that NGFI-A can compete with $\mathrm{Sp} 1$ for binding to overlapping consensus binding sites and thereby downregulate the expression of the adenosine deaminase gene (Ackerman et al., 1991) and that NGFI-B regulates the expression of the gene encoding steroid 21-hydroxylase (Wilson et al., 1993). Jun B, finally, is a member of the family of proteins that can form a dimeric activator of the AP-1 site. The fact that multiple types of possibly interacting transcription factors can be regulated by acute caffeine suggests that the changes reported here might be involved in the plastic changes following caffeine treatment

In summary, the findings presented here provide some neurochemical evidence that there is increased transmission in striatopallidal neurons after acute treatment with a stimulant dose of caffeine. They also suggests a model for further studies on the mechanism(s) underlying the biphasic effects of caffeine in striatum as well as other regions.

\section{References}

Ackerman SL, Minden AG, Williams GT, Bobonis C, Yeung C-Y (1991) Functional significance of an overlapping consensus binding motif for Sp1 and Zif268 in the murine adenosine deaminase gene promotor. Proc Natl Acad Sci USA 88:7523-7527.

Alexander SP, Reddington M (1989) The cellular localization of adenosine receptors in rat striatum. Neuroscience 28:645-651.

Angel P, Hattori K, Smeal T, Karin M (1988) The jun protooncogene is positively autoregulated by its product, Jun/AP-1. Cell 55:875-885.

Bhat RV, Cole AJ, Baraban JM (1992) Chronic cocaine treatment suppresses basal expression of zif 268 in rat forebrain: in situ hybridization studies. J Pharmacol Exp Ther 263:343-349.

Bona E, Ådén U, Fredholm BB, Hagberg H (1995) The effect of long term caffeine treatment on hypoxic-ischemic brain damage in the neonate. Pediatr Res 38:312-318.

Christy B, Nathans D (1989) DNA binding site of the growth factorinducible protein Zif268. Proc Natl Acad Sci USA 86:8737-8741.

Christy BA, Lau LF, Nathans D (1988) A gene activated in mouse 3T3 cells by growth factors encodes a protein with "zinc finger" sequences. Proc Natl Acad Sci USA 85:7857-7861.

Cole DG, Di Figlia M (1994) Reserpine increases Fos activity in the rat basal ganglia via a quinpirole-sensitive mechanism. Neurosciencc 60:115-123.

Cole AJ, Bhat RV, Patt C, Worley PF, Baraban JM (1992) D, dopamine receptor activation of multiple transcription factor genes in rat striatum. J Neurochem 58:1420-1426.

Daly JW (1993) Mechanism of action of caffeine. In: Caffeine, coffee, and health (Garattini S, ed), pp 97-150. New York: Raven.

de Groot RP, Auwerx J, Karperien M, Staels B, Kruijer W (1991) Activation of junB and PKC and PKA signal transduction through a novel cis-acting element. Nucleic Acids Res 19:775-781.

Ericson E, Samuelsson J, Ahlenius S (1991) Photocell measurements of rat motor activity. J Pharmacol Methods 25:111-122.

Fastbom J, Pazos A, Palacios JM (1987) The distribution of adenosine $\mathrm{A}_{1}$-receptors and $5^{\prime}$-nucleotidase in the brain of some commonly used experimental animals. Neuroscience 22:813-826.

Ferre S, von Euler G, Johansson B, Fredholm BB, Fuxe K (1991) Stimulation of high-affinity adenosine $A_{2}$ receptors decreases the affinity of dopamine $\mathrm{D}_{2}$ receptors in rat striatal membranes. Proc Natl Acad Sci USA 88:7238-7241.

Ferré S, Fuxe K, von Euler G, Johansson B, Fredholm BB (1992) 
Adenosine-dopamine interactions in the brain. Neuroscience 51:501512.

Ferré S, O'Connor WT, Fuxe K, Ungerstedt U (1993) The striopallidal neuron: a main locus for adenosine-dopamine interactions in the brain. J Neurosci 13:5402-5406.

Fink JS, Weaver DR, Rivkees SA, Peterfreund R, Pollak R, Adler E, Reppert SM (1992) Molecular cloning of a rat $A_{2}$ adenosine receptor: selective co-expression with $\mathrm{D}_{2}$ dopamine receptors in rat striatum. Mol Brain Res 14:186-195.

Fredholm BB (1977) Activation of adenylate cyclase from rat striatum and tuberculum olfactorium by adenosine. Med Biol 55:262-267.

Fredholm BB (1980) Are methylxanthine effects due to antagonism of endogenous adenosine? Trends Pharmacol Sci 1:129-132.

Fredholm BB (1982) Adenosine actions and adenosine receptors after 1 week treatment with caffeine. Acta Physiol Scand 115:283-286.

Fredholm BB (1985) On the mechanism of action of theophylline and caffeine. Acta Med Scand 217:149-153.

Fredholm BB (1995) Adenosine, adenosine receptors and the actions of caffeine. Pharmacol Toxicol 76:93-101.

Fredholm BB, Dunwiddie TV (1988) How does adenosine inhibit transmitter release? Trends Pharmacol Sci 9:130-134.

Fredholm BB, Fuxe K, Agnati L (1976) Effect of some phosphodiesterase inhibitors on central dopamine mechanisms. Eur J Pharmacol $38: 31-38$

Frcdholm BB, Abbracchio MP, Burnstock G, Daly JW, Harden TK, Jacobson KA, Leff P, Williams M (1994) Nomenclature and classification of purinoceptors. Pharmacol Rev 46:143-156.

Fuxe K, Ungerstedt $\mathbf{U}$ (1974) Action of caffeine and theophyllamine on supersensitive dopamine receptors: considerable enhancement of receptor response to treatment with DOPA and dopamine receptor agonists. Med Biol 52:48.

Garrett BE, Holtzman SG (1994a) Caffeine cross-tolerance to selective dopamine $D_{1}$ and $D_{2}$ receptor agonists but not to their synergistic interaction. Eur J Pharmacol 262:65-75.

Garrett BE, Holtzman SG (1994b) $\mathrm{D}_{1}$ and $\mathrm{D}_{2}$ dopamine receptor antagonists block caffeine induced stimulation of locomotor activity in rats. Pharmacol Biochem Behav 47:89-94.

Georgiev V, Johansson B, Fredholm BB (1993) Long-term caffeine treatment leads to a decreased susceptibility to NMDA-induced clonic seizures in mice without changes in adenosine $A_{1}$ receptor number. Brain Res 612:271-277.

Govoni S, Petkov VV, Montefusco O, Missale C, Battaini F, Spano SF, Trabucchi M (1984) Differential effects of caffeine on hydroxyphenylacetic acid concentrations in various rat brain dopaminergic structures. J Pharm Pharmacol 36:458-460.

Griffiths RR, Woodson PP (1988) Reinforcing effects of caffeine in humans. J Pharmacol Exp Ther 246:21-28.

Hazel TG, Nathans D, Lau LF (1988) A gene inducible by serum growth factors encodes a member of the steroid and thyroid hormone receptor superfamily. Proc Natl Acad Sci USA 85:8444-8448.

Holtzman SG, Finn IB (1988) Tolerance to behavioral effects of caffeine in rats. Pharmacol Biochem Behav 29:411-418.

Hughes P, Dragunow M (1995) Induction of immediate-early genes and the control of neurotransmitter-regulated gene expression within the nervous system. Pharmacol Rev 47:133-178.

Johansson B, Ahlberg S, van der Ploeg I, Brené S, Lindefors N, Persson $\mathrm{H}$, Fredholm BB (1993a) Effect of long term caffeine treatment on $A_{1}$ and $A_{2}$ adenosine receptor binding and on mRNA levels. NaunynSchmiedeberg's Arch Pharmacol 347:407-414.

Johansson B, Georgiev V, Parkinson FE, Fredholm BB (1993b) The binding of the adenosine $\Lambda_{2}$ selective agonist $\left[{ }^{3}\right.$ H]CGS 21680 to rat cortex differs from its binding to rat striatum. Eur J Pharmacol Mol Pharmacol Sect 247:103-110.

Johansson B, Lindström K, Fredholm BB (1994) Differences in the regional and cellular localization of c-fos mRNA induced by amphetamine, cocaine and caffeine in the rat. Neuroscience 59:837-849.

Josselyn SA, Beninger RJ (1991) Behavioral effects of intrastriatal caffeine mediated by adenosinergic modulation of dopamine. Pharmacol Biochem Behav 39:97-103.

Karasawa T, Furukawa K, Yoshida K, Shimizu M (1976) Effect of theophylline on monoamine metabolism in the rat brain. Eur J Pharmacol 37:97-104.

Krause JE, Chirgwin JM, Carter MS, Xu S, Hershey AD (1987) Three rat preprotachykinin mRNAs encode the neuropeptides substance $P$ and neurokinin A. Proc Natl Acad Sci USA 84:881-885.
Lemaire P, Relevant O, Bravo R, Charnay P (1988) Two mouse genes encoding potential transcription factors with identical DNA-binding domains are activated by growth factors in cultured cells. Proc Natl Acad Sci USA 85:4691-4695.

Mellström B, Achaval M, Montero D, Naranjo JR, Sassone-Corsi P (1991) Differential expression of the jun family members in rat brain. Oncogene 6:1959-1964.

Merchant KM, Dorsa DM (1993) Differential induction of neurotensin and c-fos gene expression induced by typical versus atypical antipsychotics. Proc Natl Acad Sci USA 90:3447-3451.

Milbrandt J (1987) A nerve growth factor-induced gene encodes a possible transcriptional regulatory factor. Science 238:797-799.

Milbrandt J (1988) Nerve growth factor induces a gene homologous to the glucocorticoid receptor gene. Neuron 1:183-188.

Moratalla R, Robertson HA, Graybiel AM (1992) Dynamic regulation of NGFI-A (zif $268, e g r 1)$ gene expression in the striatum. J Neurosci 12:2609-2622.

Moratalla R, Vickers EA, Robertson HA, Cochran BH, Graybiel AM (1993) Coordinate expression of $\mathrm{c}-$ fos and $j u n \mathrm{~B}$ is induced in the rat striatum by cocaine. J Neurosci 13:423-433.

Mumford GK, Holtzman SG (1991) Do adenosinergic substrates mediate methylxanthine effects upon reinforcement thresholds for electrical brain stimulation in the rat? Brain Res 550:172-178.

Nakajima T, Daval JL, Morgan PF, Post RM, Marangos PJ (1989) Adenosinergic modulation of caffeine-induced c-fos mRNA expression in mouse brain. Brain Res 501:307-314.

Nehlig A, Daval JL, Debry G (1992) Caffeine and the central nervous system: mechanisms of action, biochemical, metabolic and psychostimulant effects. Brain Res Brain Res Rev 17:139-170.

Nguyen TV, Kosofsky BE, Birnbaum R, Cohen BM, Hyman SE (1992) Differential expression of $\mathrm{c}-\mathrm{Fos}$ and Zif 268 in rat striatum after haloperidol, clozapine, and amphetamine. Proc Natl Acad Sci USA 89:4270-4274.

Nikodijeviç O, Jacobson KA, Daly JW (1993) Locomotor activity in mice during chronic treatment with caffeine and withdrawal. Pharmacol Biochem Behav 44:199 216.

Parkinson FE, Fredholm BB (1990) Autoradiographic evidence for G-protein coupled $\mathrm{A}_{2}$-receptors in rat neostriatum using $\left[{ }^{3} \mathrm{H}\right]$-CGS 21680 as a ligand. Naunyn-Schmiedeberg's Arch Pharmacol 342:8589.

Paul ML, Graybiel AM, David J-C, Robertson HA (1992) D-like and $\mathrm{D}_{2}$-like dopamine receptors synergistically activate rotation and $\mathrm{c}-\mathrm{fos}$ expression in the dopamine-depleted striatum in a rat model of Parkinson's disease. J Neurosci 12:3729-3742.

Ramkumar V, Bumgarner JR, Jacobson KA, Stiles GL (1988) Multiple components of the $A_{1}$ adenosine receptor-adenylate cyclase system are regulated in rat cerebral cortex by chronic caffeine ingestion. J Clin Invest 82:242-247.

Robertson GS, Vincent SR, Fibiger HC (1992) $D_{1}$ and $D_{2}$ dopamine receptors differentially regulate c-fos expression in striatonigral and striatopallidal neurons. Neuroscience 49:285-296.

Ryder K, Lau LF, Nathans D (1988) A gene activated by growth factors is related to the oncogene v-jun. Proc Natl Acad Sci USA 85:14871491.

Sagar SM, Sharp FR, Curran T (1988) Expression of c-fos protein in brain: metabolic mapping at the cellular level. Science 240:1328 1331.

Schiffmann SN, Jacohs O, Vanderhaeghen IJ (1991) Striatal restricted adenosine $\mathrm{A}_{2}$ receptor (RDC8) is expressed by enkephalin but not by substance P neurons: an in situ hybridization histochemistry study. J Neurochem 57:1062-1067.

Schlingensiepen K-H, Lüno K, Brysch W (1991) High basal expression of the zif/268 immediate early gene in cortical layers IV and VI, in CA1 and in the corpus striatum - an in situ hybridization study. Neurosci Lett 122:67-70.

Senogles SE (1994) The $D_{2}$ dopamine receptor isoforms signal through distinct $G_{i} \propto$ proteins to inhibit adenylyl cyclase. A study with sitedirected mutant $\mathrm{G}_{i} \propto$ proteins. J Biol Chem 269:23120-23127.

Sharp FR, Sagar SM, Hicks K, Lowenstein D, Hisanaga K (1991) cfos mRNA, Fos, and Fos-related antigen induction by hypertonic saline and stress. J Neurosci 11:2321-2331.

Sheng M, Greenberg ME (1990) The regulation and function of c-fos and other immediate early genes in the nervous system. Neuron 4:477-485.

Shi D, Nikodijevic O, Jacobson KA, Daly JW (1993) Chronic caffeine 
alters the density of adenosine, adrenergic, cholinergic, GABA, and serotonin receptors and calcium channels in mouse brain. Cell $\mathrm{Mol}$ Neurobiol 13:24\%-261.

Sukhatme VP, Kartha S, Toback FG, Taub R, Hoover RG, Tsai-Morris C-H (1987) A novel early growth response gene rapidly induced by fibroblast, epithelial cell and lymphocyte mitogens. Oncogene Res $1: 343-355$

Svenningsson P, Ström A, Johansson B, Fredholm BB (1995) Increased expression of c-jun, jun $\mathrm{B}, \mathrm{AP}-1$ and preproenkephalin mRNA in rat striatum following a single injection of caffeine. J Neurosci 15:35833893.

Svenningsson P, Johansson B, Fredholm BB (1996) Caffeine-induced expression of c-fos mRNA and NGFI-A mRNA in caudate-putamen and in nucleus accumbens are differentially affected by the $N$-methylD-aspartate receptor antagonist MK-801. Mol Brain Res, in press.

Tsai-Morris C-H, Cao X, Sukhatme VP (1988) 5' flanking sequence and genomic structure of EGR-1, a murine mitogen inducible zinc finger encoding gene. Nucleic Acids Res 16:8835-8846.

Waldeck B (1971) Some effects of caffeine and aminophylline on the turnover of catecholamines in the brain. J Pharm Pharmacol 23:824830 .
Watson MA, Milbrandt J (1989) The NGFI-B gene, a transcriptionally inducible member of the steroid receptor gene superfamily: genomic structure and expression in ral brain after seizure induction. Mol Cell Biol 9:4213-4219.

Watson MA, Milbrandt J (1990) Expression of the nerve growth factorregulated NGFI-A and NGFI-B genes in the developing rat. Development 110:173-183.

Wilson TE, Fahrner TJ, Johnston M, Milbrandt J (1991) Identification of the DNA binding site for NGFI-B by genetic selection in yeast. Science 262:1296-1300.

Wilson TE, Mouw AR, Weaver CA, Milbrandt J, Parker KL (1993) The orphan nuclear receptor NGFI-B regulates expression of the gene encoding steroid 21-hydroxylase. Mol Cell Biol 13:861-868.

Wisden W, Errington ML, Williams S, Dunnitt SB, Waters C. Hitchcock D, Evan G, Bliss TVP, Hunt SP (1990) Differential expression of immediate early genes in the hippocampus and spinal cord. Neuron 4:603-614.

Worley PF, Christy BA, Nakabeppu Y, Bhat RV, Cole AJ, Baraban JM (1991) Constitutive expression of zif268 in neocortex is regulated by synaptic activity. Proc Natl Acad Sci USA 88:5106-5110.

Yoshikawa K, Williams C, Sabol SL (1984) Rat brain preproenkephalin mRNA. J Biol Chem 259:14301-14308. 